\title{
ERRATUM
}

\section{Ouabain exerts biphasic effects on connexin functionality and expression in vascular smooth muscle cells}

\author{
${ }^{1,4}$ Patricia E.M. Martin, ${ }^{1}$ Nathan S. Hill, ${ }^{2}$ Bo Kristensen, ${ }^{3}$ Rachael J. Errington \& \\ *,1Tudor M. Griffith
}

Correction to: British Journal of Pharmacology (2003) 140, 1261-1271. doi:10.1038/sj.bjp.0705556

${ }^{1}$ Department of Diagnostic Radiology, University of Wales College of Medicine, Heath Park, Cardiff CF14 4XN; ${ }^{2}$ Biomembrane Center, The August Krogh Institute, Universitetsparken 13, Copenhagen, DK-2100, Denmark and ${ }^{3}$ Department of Medical Biochemistry, University of Wales College of Medicine, Heath Park, Cardiff CF14 4XN

1 We have compared the effects of ouabain on the maintenance of gap junctional communication in rat aortic A7r5 smooth muscle cells, monkey COS-1 fibroblasts and human HeLa epithelial cells.

2 Ouabain $(1 \mathrm{mM})$ interrupted dye coupling between confluent A7r5 cells within $\sim 1 \mathrm{~h}$, and high concentrations of ouabain were similarly required to reduce coupling between COS- 1 cells selected to express the rat $\alpha_{1} \mathrm{Na}^{+} / \mathrm{K}^{+}$-ATPase subunit, which is ouabain resistant. By contrast, low concentrations of ouabain $(1-10 \mu \mathrm{M})$ attenuated dye transfer in wild-type COS-1 and HeLa cells, whose endogenous $\alpha_{1}$ subunits possess relatively high affinity for the glycoside $\left(\mathrm{K}_{\mathrm{i}} \sim 0.3 \mathrm{vs} \sim 100 \mu \mathrm{M}\right)$ Ouabain-induced reductions in dye transfer therefore correlated with the ability of the glycoside to bind to the $\mathrm{Na}^{+} / \mathrm{K}^{+}$-ATPase isoenzymes expressed in these different cell lines.

3 No consistent relationship between inhibition of intercellular dye transfer and secondary changes in $\left[\mathrm{Ca}^{2+}\right]_{\mathrm{i}}$ or $\mathrm{pH}_{\mathrm{i}}$ could be identified following incubation with ouabain.

4 In separate experiments, the effects of ouabain on real-time trafficking of connexin $(\mathrm{Cx})$ protein were monitored by time-lapse microscopy of A7r5 cells transfected to express a fluorescent $\mathrm{Cx} 43$-green fluorescent protein (GFP) and the ability of the glycoside to modulate endogenous expression of $\mathrm{Cx} 40$ and $\mathrm{Cx} 43$ evaluated in A7r5 cells by immunochemical and Western blot analysis.

5 Ouabain $(1 \mathrm{mM})$ depressed vesicular trafficking of Cx43-GFP after $\sim 1 \mathrm{~h}$, and caused a time-dependent loss of endogenous $\mathrm{Cx} 40$ and $\mathrm{Cx} 43$ protein that was first evident at $2 \mathrm{~h}$ and almost complete after $4 \mathrm{~h}$. These effects of ouabain on Cx expression were reversed $\sim 90 \mathrm{~min}$ following washout of the glycoside.

6 We conclude that ouabain exerts biphasic effects on intercellular communication that involve an initial decrease in gap junctional permeability followed by a global reduction in the expression of $\mathrm{Cx}$ protein. Further studies are necessary to establish to what extent these actions of ouabain reflect inversion of the normal $\left[\mathrm{Na}^{+}\right]_{\mathrm{i}} /\left[\mathrm{K}^{+}\right]_{\mathrm{i}}$ ratio and/or conversion of the $\mathrm{Na}^{+} / \mathrm{K}^{+}$-ATPase into a general signal transducer that regulates downstream protein synthesis.

British Journal of Pharmacology (2004) 141, 374-384. doi:10.1038/sj.bjp.0705671

Keywords: Cell communication; gap junctions; EDHF

Abbreviations: BCECF, 2',7', -bis(2-carboxyethyl)-5(6)-carboxyfluorescein; Cx, connexin; DMEM, Dulbecco's modified Eagle's medium; DMSO, dimethyl sulphoxide; DTT, dithiothreitol; GFP, green fluorescent protein; PBS, phosphatebuffered saline; HBS, HEPES-buffered saline; fura-2 AM, 5-oxazolecarboxylic acid, 2-[6-[bis[2-acetyloxy)methoxy]-2-oxoethyl]amino]-5-[2-[2-[bis[2-[(acetyloxy)methoxy]-2-oxoethyl]amino]-5-methylphenoxy]ethoxy]-2benzofuranyl]-, (acetyloxy)methyl ester

\section{Introduction}

The glycoside ouabain, which binds to the membrane $\mathrm{Na}^{+} / \mathrm{K}^{+}$ -ATPase, affects cell function by modulating ionic homeostasis and intracellular signal transduction cascades, ultimately leading to changes in the expression of a wide range of intracellular proteins (Blanco \& Mercer, 1998; Haas et al., 2002; Taurin et al., 2002). Since the $\mathrm{Na}^{+} / \mathrm{K}^{+}$-ATPase is electrogenic, in vascular smooth muscle ouabain may promote an increase in contractile tone by causing membrane depolarization and thereby increasing $\mathrm{Ca}^{2+}$ influx via voltage-

*Author for correspondence; E-mail: griffith@cardiff.ac.uk ${ }^{4}$ Current address: Department Medical Biochemistry, University of Wales College of Medicine, Heath Park, Cardiff CF14 4XN, U.K. dependent $\mathrm{Ca}^{2+}$ channels (Sato \& Aoki, 1991). The loss of ionic pump activity that follows binding of ouabain also contributes to elevations in tone by elevating $\left[\mathrm{Na}^{+}\right]_{\mathrm{i}}$ and causing a secondary increase in $\left[\mathrm{Ca}^{2+}\right]_{\mathrm{i}}$ via $\mathrm{Na}^{+}{ }_{-} \mathrm{Ca}^{2+}$ exchange (Sato \& Aoki, 1991; Borin et al., 1994). The glycoside may additionally modulate vascular function by attenuating agonist-induced relaxations that are mediated via the endothelium, but are independent of nitric oxide (NO) and vasodilator prostanoids. Among the mechanisms postulated to contribute to such responses is an extracellular release of $\mathrm{K}^{+}$ associated with activation of endothelial $\mathrm{K}_{\mathrm{Ca}}$ channels. In this scenario, $\mathrm{K}^{+}$serves as a freely transferable endotheliumderived hyperpolarizing factor (EDHF) and ouabain has been 
hypothesized to attenuate relaxation by blocking the increase in $\mathrm{Na}^{+} / \mathrm{K}^{+}$-ATPase activity that results from elevated $\left[\mathrm{K}^{+}\right]_{\mathrm{o}}$ (Edwards et al., 1998). Alternatively, ouabain might impair $\mathrm{NO} /$ prostanoid-independent relaxations by attenuating the electrotonic spread of agonist-induced endothelial hyperpolarization into the vascular wall (Griffith et al., 2002; Sandow et al., 2002), since the glycoside is also able to block signalling via gap junctions (Schirrmacher et al., 1996; Harris et al., 2000). These intercellular communication channels allow direct transfer of ions and small polar molecules $<1 \mathrm{kDa}$ in size, thereby conferring electrical continuity between coupled cells, and are constructed from connexins $(\mathrm{Cx})$, a highly conserved group of at least 20 distinct proteins, of which the Cx37, 40, 43 and 45 subtypes (designated according to molecular mass in $\mathrm{kDa}$ ) are found in the vasculature (Chaytor et al., 2001; Ko et al., 2001; Kruger et al., 2002; Berman et al., 2002; Hill et al., 2002; Ujiie et al., 2003). Since the ability of ouabain to interrupt direct intercellular signalling has not previously been investigated in vascular cells, in the present study we have examined the role of the $\mathrm{Na}^{+} / \mathrm{K}^{+}$-ATPase in maintaining gap junctional communication in rat aortic A7r5 myocytes. These cells are highly coupled and exhibit abundant expression of Cx43 and Cx40 in gap junction plaques at points of cell-cell contact (Chaytor et al., 2001).

The minimal functional unit of the $\mathrm{Na}^{+} / \mathrm{K}^{+}$-ATPase is a heterodimer consisting of a catalytic $\alpha$-subunit and a regulatory $\beta$-subunit (Blanco \& Mercer, 1998). Four $\alpha$ - and three $\beta$-isoforms have been characterized and are expressed as various combinations in a cell- and tissue-specific manner (Juhaszova \& Blaustein, 1997; Blanco \& Mercer, 1998). All such isoenzymes are inhibited by ouabain, although its potency may vary. Many cells express an $\alpha_{1}$ isoform that is highly sensitive to ouabain, but mutations in the binding site render the rodent $\alpha_{1}$ subunit relatively ouabain-resistant (Vilsen, 1999). In the present study, we have exploited the ability of the rat $\alpha_{1}$ subunit to heterodimerize with $\beta$ subunits in COS- 1 cells to construct a model cell system that expresses the ouabainresistant rodent pump (Belusa et al., 2002; Kristensen et al., 2003a). Comparison of the effects of ouabain on dye transfer of Lucifer yellow in A7r5 cells, wild-type (wt) and ouabainresistant (oubR) COS-1 cells was then used to confirm the specific role of the $\mathrm{Na}^{+} / \mathrm{K}^{+}$-ATPase in the maintenance of gap junctional communication. Analogous experiments were also performed in HeLa cells, rendered communication competent by selection to express a chimeric $\mathrm{Cx} 43$-green fluorescent protein (GFP), and in which the $\alpha_{1}$ subunit is ouabain sensitive (Martin et al., 2001; Berman et al., 2002). In osteoblastic cells, the ability of ouabain to impair intercellular communication has been hypothesized to result from the increase in $\left[\mathrm{Ca}^{2+}\right]_{\mathrm{i}}$ that follows inhibition of the $\mathrm{Na}^{+} / \mathrm{K}^{+}$ATPase (Schirrmacher et al., 1996). However, it is also conceivable that secondary changes in intracellular $\mathrm{pH}$, which may follow loss of the ionic activity of the pump in some cell types (Arisaka et al., 1988; Souza et al., 2000), modulate gap junction permeability, since intracellular acidification can reduce the permeability of gap junctions (Morley et al., 1996). We therefore investigated if the effects of ouabain on dye transfer in A7r5 cells, wtCOS cells and oubRCOS cells could be linked to changes in $\left[\mathrm{Ca}^{2+}\right]_{\mathrm{i}}$ and $\mathrm{pH}_{\mathrm{i}}$ that might follow blockade of the $\mathrm{Na}^{+} / \mathrm{K}^{+}$-ATPase. Finally, given the ability of ouabain to modulate protein expression (Taurin et al., 2002), and the short half-life of Cx proteins, for example,
1-2 h for Cx43 (Darrow et al., 1995; Saffitz et al., 2000), we examined the effects of the glycoside on real-time trafficking of $\mathrm{Cx}$ protein in A7r5 cells transfected to express Cx43-GFP (Martin et al., 2001) and the effects of longer-term incubation $(2-4 h)$ on the expression of endogenous Cx40 and Cx43 by immunocytochemical and Western blot analysis of control A7r5 cells. Taken together, the findings demonstrate the existence of a previously unrecognized biphasic effect of ouabain on gap junction functionality and $\mathrm{Cx}$ expression in vascular smooth muscle.

\section{Methods}

\section{Cell culture and transfection}

The rat aortic smooth muscle A7r5 cell line, the human HeLa Ohio epithelial cell line and the monkey kidney fibroblast COS-1 cell line were maintained in complete DMEM (Chaytor et al., 2001; Martin et al., 2001). For HeLa cells selected to express Cx43-GFP, the medium was supplemented with geneticin sulphate (G418-sulphate, $4 \mathrm{mg} \mathrm{ml}^{-1}$ ) (Martin et al., 2001; Berman et al., 2002). COS-1 cells resistant to ouabain were generated by transfection with rat $\alpha_{1} \mathrm{Na}^{+} / \mathrm{K}^{+}$-ATPase cDNA and were maintained in complete DMEM containing $10 \mu \mathrm{M}$ ouabain as previously described (Kristensen et al., 2003a). For dye transfer studies, cells were grown on $60 \mathrm{~mm}$ tissue culture dishes. A7r5 cells were transiently transfected with $0.25 \mu \mathrm{g} \mathrm{Cx} 43$ GFP cDNA using Lipofectamine 2000. For immunocytochemistry, timelapse microscopy, and $\mathrm{Ca}^{2+}$ and $\mathrm{pH}$ measurements cells were cultured in $24 \mathrm{~mm}^{2}$ coverglass chambers.

\section{Gap junction functionality}

The role of the $\mathrm{Na}^{+} / \mathrm{K}^{+}$-ATPase in maintaining cell to cell coupling was assessed by studying the effects of $60 \mathrm{~min}$ incubation with ouabain $(1 \mu \mathrm{M}-1 \mathrm{mM})$ on dye transfer of Lucifer yellow $\mathrm{CH}$ (charge -2, MW $457 \mathrm{Da}$ ). At $15 \mathrm{~min}$ following intracytoplasmic microinjection of individual cells within confluent monolayers, the cultures were fixed in $4 \% \mathrm{w} / \mathrm{v}$ paraformaldehyde and the percentage of injections resulting in dye transfer to different numbers of neighbouring cells assessed on a Zeiss Axiovert fluorescence microscope (Martin et al., 2001; Berman et al., 2002).

\section{Intracellular calcium and $\mathrm{pH}$ levels}

For intracellular $\mathrm{Ca}^{2+}$ measurements A7r5, COS-1 and HeLa cells were loaded with Fura-2 AM $\left(2 \mu \mathrm{g} \mathrm{ml}^{-1}\right)$ and for $\mathrm{pH}$ measurements A7r5 and COS- 1 cells were loaded with BCECF AM $\left(1.25 \mu \mathrm{g} \mathrm{ml}^{-1}\right)$ by incubation for $20 \mathrm{~min}$ at $37^{\circ} \mathrm{C}$ in $\mathrm{HBS}$ $\left(133 \mathrm{mM} \mathrm{NaCl}, 4.2 \mathrm{mM} \mathrm{KCl}, 1 \mathrm{mM} \mathrm{MgCl}_{2}, 5.8 \mathrm{mM}\right.$ glucose, $10 \mathrm{~mm}$ HEPES, $0.1 \% \mathrm{w} / \mathrm{v}$ BSA, pH 7.5) supplemented with $1.3 \mathrm{mM} \mathrm{CaCl}_{2}$. Cells were viewed on a fluorescent microscope and images collected every $10 \mathrm{~s}$ for $30 \mathrm{~min}$ on a heated stage maintained at $37^{\circ} \mathrm{C}$. Ouabain $(100 \mu \mathrm{M}-1 \mathrm{mM})$ was added at $30 \mathrm{~s}$. The fluorescence intensities resulting from excitation at 340 and $380 \mathrm{~nm}$ (for $\mathrm{Ca}^{2+}$ measurements) and from excitation at 480 and $440 \mathrm{~nm}$ (for $\mathrm{pH}$ measurements) were recorded using Kinetic Imaging software. The data were exported to a Microsoft Excel spreadsheet and the 340:380 and $480: 440 \mathrm{~nm}$ ratios calculated to determine changes in $\left[\mathrm{Ca}^{2+}\right]_{\mathrm{i}}$ and $\mathrm{pH}_{\mathrm{i}}$. 


\section{Immunocytochemistry}

The effects of ouabain on endogenous $\mathrm{Cx} 43$ expression in A7r5 cells were assessed with a monoclonal antibody against the carboxyl tail of $\mathrm{Cx} 43$ (1:250 dilution) and a secondary goat anti-mouse antibody conjugated to Alexa 488 (1:700 dilution) (Chaytor et al., 2001; Ujiie et al., 2003). Images were acquired with an Axiovert 100 microscope linked to a BIORAD MRC 1024MP laser scanning system, typically under a $\times 40$ lens, with a gain of 930 and Iris 4 and a Kalman filter (16 scans). Quantification of the fluorescence distribution before and after treatment with ouabain was assessed by analysing up to 10 regions of equal area along the plasma membrane per field of view and recording their fluorescent intensity. To obtain a mean pixel intensity, four to five images were analysed in this way for each experimental group and similarly defined areas selected to estimate background fluorescence which was subtracted from the mean pixel intensity of membrane fluorescence to derive a relative fluorescent index for each set of treatments.

\section{Western blot analysis}

Confluent A7r5 cells were incubated for up to $4 \mathrm{~h}$ with ouabain $(100 \mu \mathrm{M}-1 \mathrm{mM})$ and harvested in $100 \mu \mathrm{l}$ of ice-cold lysis buffer $\left(1 \% \mathrm{w} / \mathrm{v}\right.$ SDS, $1 \mathrm{~mm}$ DTT, $1 \mathrm{mM} \mathrm{NaVO}_{4}, 4 \mathrm{ng} \mathrm{ml}^{-1}$ leupeptin, $4 \mathrm{ng} \mathrm{ml}^{-1}$ apoprotinine and $1 \mathrm{mM}$ phenylmethylsulfonyl fluoride in PBS), followed by sonication. Protein content was measured using the BIORAD assay kit and equal amounts of protein $(50 \mu \mathrm{g})$ were analysed on SDS-PAGE $(10 \%)$ followed by transfer to nitrocellulose in transfer buffer $\left(20 \mathrm{mM} \mathrm{Na}_{2} \mathrm{CO}_{3}\right)$ for $3 \mathrm{~h}$ at $300 \mathrm{~mA}$. The transfer efficiency was assessed by Ponceau S staining prior to further probing with a polyclonal antibody to $\mathrm{Cx} 43$ that recognizes multiple phosphorylated/ nonphosphorylated isoforms of $\mathrm{Cx} 43$ (1:4000 dilution) or an antibody to $\mathrm{Cx} 40$ (1:1000 dilution), and a secondary goat anti-rabbit horseradish peroxidase antibody. To standardize protein expression, the blots were also probed with a monoclonal antibody against $\alpha$-tubulin (1:5000 dilution) and a secondary goat anti-mouse horseradish peroxidase antibody. Blots were developed by enhanced chemiluminescence (ECL) and analysed using a BIORAD 700 densitometer.

\section{Time lapse microscopy}

At $30 \mathrm{~h}$ post-transfection of A7r5 cells with Cx43-GFP, the cultures were washed twice in PBS and the medium replaced with $1 \mathrm{ml}$ of $\mathrm{HBS}$ supplemented with $1.3 \mathrm{mM} \mathrm{CaCl}_{2}$ or $\mathrm{HBS}$ containing only trace $\mathrm{Ca}^{2+}$. Time-lapse sequences were acquired using a $\times 401.3$ oil immersion lens to provide image sequences in $15 \mathrm{~min}$ batches (60 images of $15 \mathrm{~s}$ length), which enabled Cx trafficking to be monitored $0-15,30-45,60-$ 75 min under control conditions and following treatment with ouabain. The BIORAD Lasersharp software package was used to analyse Cx43-GFP trafficking events using an approach analogous to that used to measure spatial co-localization (Manders et al., 1993). Time points $15 \mathrm{~s}(t 1), 7.5 \mathrm{~min}(t 2)$ and $15 \mathrm{~min}(t 3)$ from each batch of images were assigned the colour channels red, green and blue, respectively (see Figure 5a). Superposition of these coloured images provided visual and quantifiable information about the dynamics of Cx43-GFP trafficking, with the relative location of red, green and blue pixels indicating the direction of trafficking towards, away from or parallel to the plasma membrane, and static vesicular $\mathrm{Cx}$ protein giving a merged image with white pixels. Comparison of time points 1 and 3 from each data set permitted the extraction of a temporal colocalization coefficient $\left(C_{\mathrm{E}}\right)$, which quantifies the number of red pixels at time point 1 that superimpose with blue pixels at time point 3 (Martin et al., 2001). As the value of $C_{\mathrm{E}}$ tends towards 0 the extent of overlap is small as a result of Cx43-GFP intensities changing position. By contrast, if the value approaches 1 then the extent of overlap was large indicating no movement. The extent of temporal overlap can also be represented on a pixelby-pixel basis by a scatter plot showing the distribution at $t 1$ (red axis) compared with $t 3$ (blue axis). Complete colocalization is shown along the line of identity (Martin et al., 2001).

\section{Cell viability}

Cell viability was assessed by loading cells with $2.5 \mu \mathrm{M}$ calcein $\mathrm{AM}$ for $15 \mathrm{~min}$ in complete medium at $37^{\circ} \mathrm{C}$, followed by three washes in HBS containing $1.3 \mathrm{mM} \mathrm{Ca}^{2+}$. Cells were also incubated with $5 \mu \mathrm{g} \mathrm{ml}^{-1}$ propidium iodide for $5 \mathrm{~min}$ and viewed on a confocal laser-scanning microscope with dual excitation spectra of 488 and $567 \mathrm{~nm}$ and emissions of 530/540 and $580 \mathrm{~nm}$ LP for calcein and propidium iodide, respectively.

\section{Materials}

All cell lines used were obtained from ECACC, Wiltshire, U.K. DMEM, supplements for cell growth and Lipafectamine 2000 were supplied by Invitrogen (Glasgow, U.K.). G418sulphate was purchased from Promega (Southampton, U.K.) and Lucifer yellow, Fura2 AM, BCECF, calcein AM and goat anti-rabbit Alexa488 were obtained from Molecular Probes (Leiden, Netherlands). The Cx43 monoclonal antibody used for immunofluorescence and the $\alpha$-tubulin antibody were supplied by Chemicon (Chandlers Ford, U.K.). Other antibodies for Western blotting of $\mathrm{Cx} 43$ and $\mathrm{Cx} 40$ were obtained from Zymed (Cambridge, U.K.) and Alpha Diagnostics (San Antonio, U.S.A.), respectively. The goat antimouse horseradish peroxidase was supplied by BioRad (Hemel Hempsted, U.K.) and the ECL system from Pierce (Tattenhall, U.K.). All other reagents were supplied by Sigma (Poole, U.K.). Ouabain was dissolved initially in DMSO to give a stock solution of $0.1 \mathrm{M}$. In control experiments, DMSO was inactive at the final concentrations employed. Other agents were dissolved directly in buffer.

\section{Statistics}

Data were evaluated by ANOVA followed by Dunnett's multiple comparison test, with $P<0.05$. being considered significant.

\section{Results}

\section{Gap junction functionality}

Under control conditions more than $80 \%$ of A7r5 cells transferred dye to $>10$ neighbours. Ouabain at $300 \mu \mathrm{M}$ and $1 \mathrm{mM}$ attenuated coupling to $>10$ neighbours by $\sim 70 \%$ 

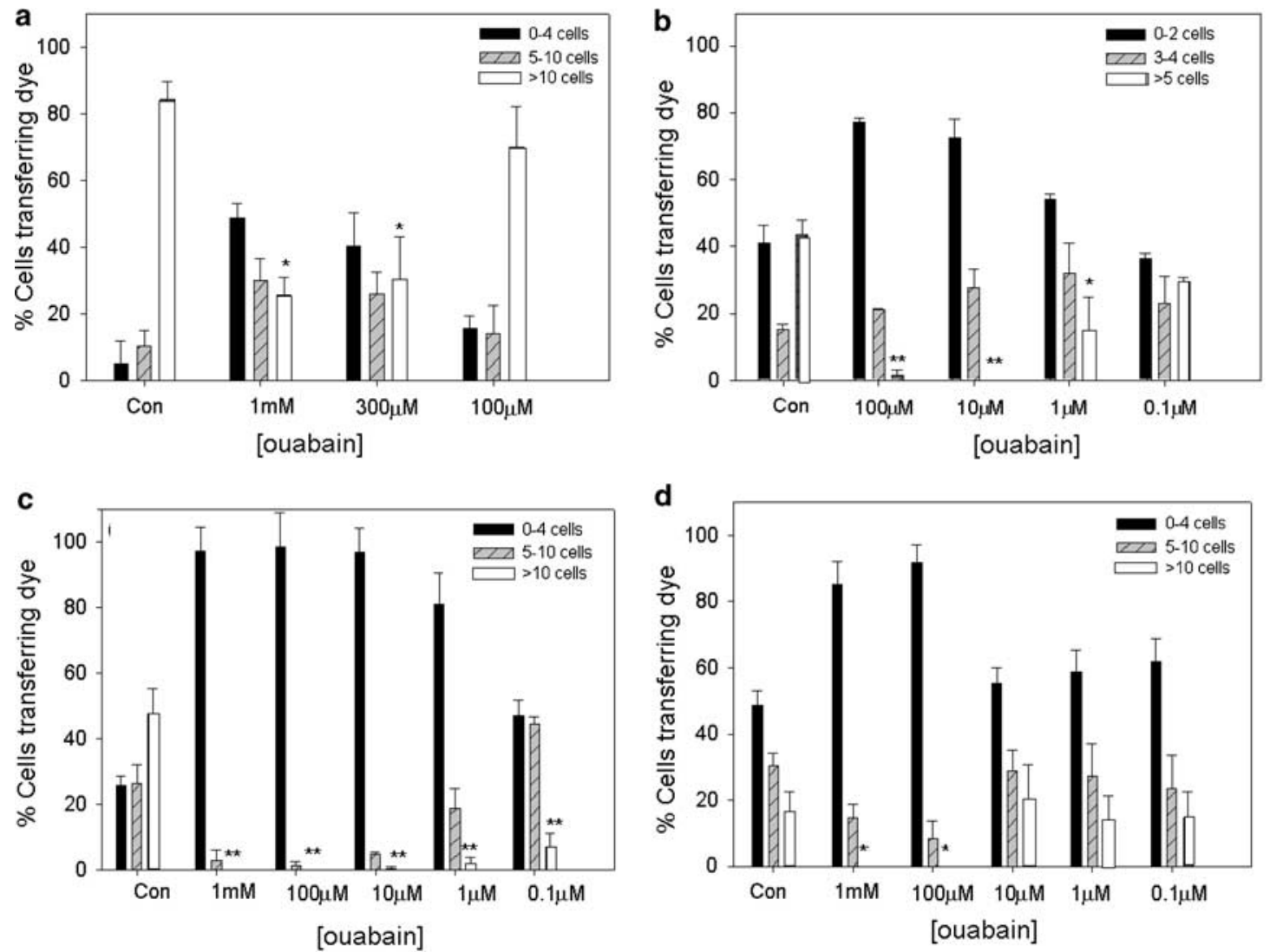

Figure 1 Inhibitory effects of ouabain on dye coupling in A7r5 cells (a), HeLa cells expressing Cx43-GFP (b), wild-type COS-1 cells (c) and ouabain-resistant COS-1 cells (d). Results are expressed as the percentage of cells transferring Lucifer yellow to 0-4, $5-10$ and $>10$ neighbours (for A7r5 and COS cultures) and to $0-2,3-4$ and $>5$ neighbours in HeLa cultures (because of lower dye coupling). Experiments were performed in triplicate with $>50$ injections per plate, and this protocol repeated three times. Data are shown as mean \pm s.e.m. Asterisks indicate significant effects of ouabain on the highest level of coupling compared to control $* P<0.05, * * P<0.005$.

$(P<0.01)$, whereas incubation with $100 \mu \mathrm{M}$ was without effect (Figure 1a). Under control conditions $\sim 50 \%$ of HeLa cells selected to express Cx43-GFP transferred dye to $>5$ neighbours and ouabain attenuated coupling by $\sim 90 \%$ at 100 and $10 \mu \mathrm{M}(P<0.01)$, by $\sim 70 \%$ at $1 \mu \mathrm{M}(P<0.01)$, but was without effect at $0.1 \mu \mathrm{M}$ (Figure $1 \mathrm{~b}$ ).

Under control conditions wt and oubRCOS-1 cells both transferred dye to $>10$ neighbours (Figure 1c,d). Treatment of either population with $1 \mathrm{mM}$ or $100 \mu \mathrm{M}$ ouabain attenuated dye transfer to $>10$ cells by $\sim 90 \% \quad(P<0.05)$. Ouabain at concentrations of $0.1,1$ and $10 \mu \mathrm{M}$ significantly attenuated dye transfer in wt cells, but was without effect in oubR cells (Figure 1c,d). This difference is to be expected, as although the abundance ratio of the endogenous and rat $\alpha_{1} \mathrm{Na}^{+} / \mathrm{K}^{+}$ATPase is close to unity in oubRCOS cells (Kristensen et al., 2003a), they were continuously maintained in $10 \mu \mathrm{M}$ ouabain. For reasons that are unclear, under baseline conditions, the percentage of oubR cells transferring dye at the highest level (to $>10$ neighbours) was only $\sim 30 \%$ of that of wt cells.

\section{Intracellular $\mathrm{Ca}^{2+}$ and $\mathrm{pH}$ levels}

Under control conditions, A7r5 cells maintained a steady basal $\left[\mathrm{Ca}^{2+}\right]_{\mathrm{i}}$ with a $340: 380$ ratio of $\sim 1$. Treatment with $100 \mu \mathrm{M}$ ouabain induced a transient increase in $\left[\mathrm{Ca}^{2+}\right]_{\mathrm{i}}$ that peaked at $\sim 20 \mathrm{~min}$ before declining, whereas $1 \mathrm{mM}$ ouabain induced a monotonic increase in $\left[\mathrm{Ca}^{2+}\right]_{\mathrm{i}}$ over $30 \mathrm{~min}$ (Figure 2a). By contrast, $100 \mu \mathrm{M}$ ouabain had no effect on basal $\left[\mathrm{Ca}^{2+}\right]_{\mathrm{i}}$ in HeLa cells expressing Cx43-GFP or oubRCOS- 1 cells, whereas a small increase in $\left[\mathrm{Ca}^{2+}\right]_{\mathrm{i}}$ was observed in wtCOS-1 cells (Figure 2a). ATP $(80 \mu \mathrm{M})$ induced $\mathrm{Ca}^{2+}$ transients in both COS cell lines (Figure $2 b$ ).

Under control conditions, A7r5 and wt and oubRCOS cells loaded with BCEFC AM maintained a steady basal $\mathrm{pH}_{\mathrm{i}}$ with a $480: 440 \mathrm{~nm}$ ratio of $\sim 1$ (Figure 2c). Following treatment with $1 \mathrm{mM}$ or $100 \mu \mathrm{M}$ ouabain, $\mathrm{pH}_{\mathrm{i}}$ remained constant (Figure $2 \mathrm{c}$ ), whereas $10 \mathrm{mM} \mathrm{NH} \mathrm{NH}_{4} \mathrm{Cl}$ induced a rapid initial alkalinization followed by over-acidification on washout (Roos \& Boron, 1981) (Figure 2d).

\section{Endogenous connexin expression}

Treatment of A7r5 cells with $100 \mu \mathrm{M}$ or $300 \mu \mathrm{M}$ ouabain for $2 \mathrm{~h}$ had no effect on the incidence of plaques at regions of cell-tocell contact (Figure 3). After $1 \mathrm{~h}$ incubation with $1 \mathrm{~mm}$ ouabain, plaques in the plasma membrane similarly remained intact with levels of fluorescence not differing from control, whereas after $2 \mathrm{~h}$ there was a reduction in membrane $\mathrm{Cx} 43$ staining of up to $50 \%$, and by $4 \mathrm{~h}$ all $\mathrm{Cx} 43$ staining was lost (Figure 3).

Western analysis of extracts of A7r5 cells indicated that these cells expressed Cx43 in nonphosphorylated (NP) and P1 


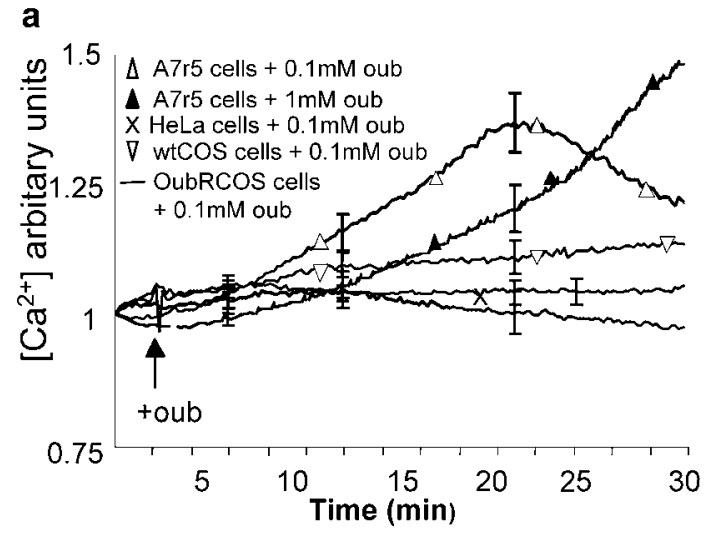

C

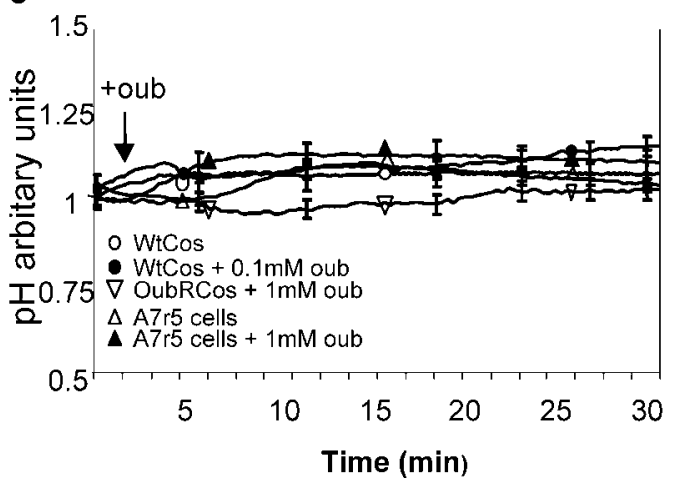

b

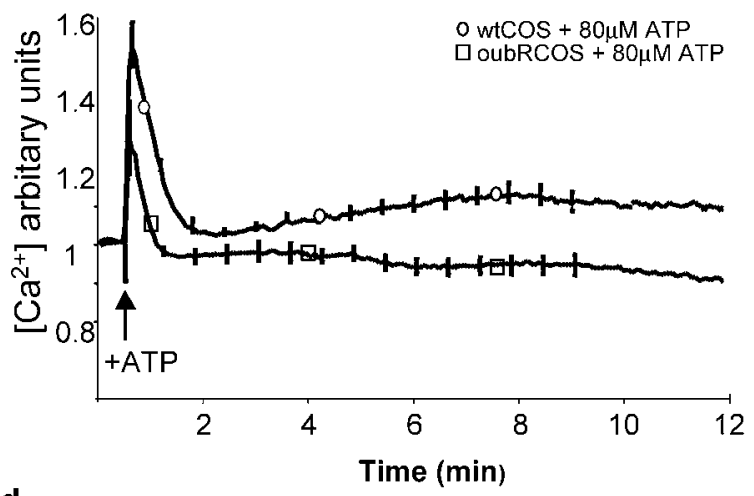

d

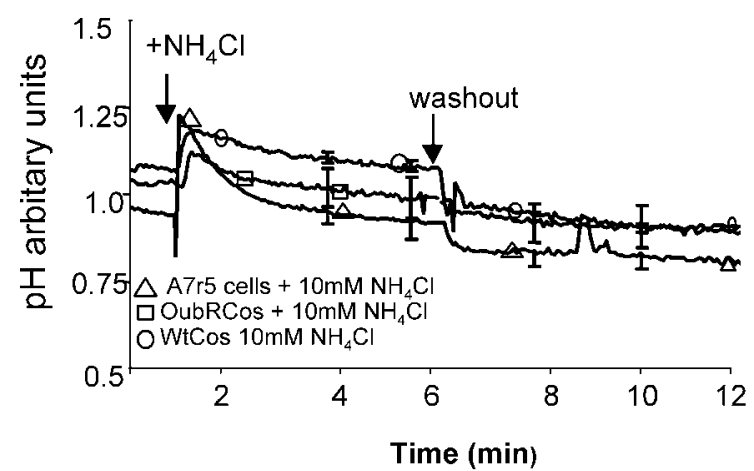

Figure 2 Effects of ouabain on intracellular $\left[\mathrm{Ca}^{2+}\right]$ and $\mathrm{pH}$. (a) Fura 2 fluorescence before and during exposure of HeLa, wtCOS, oubRCOS and A7r5 cells to $100 \mu \mathrm{M}$ ouabain. A7r5 cells were also treated with $1 \mathrm{~mm}$ ouabain. (b) Fura 2 fluorescence in wtCOS and oubRCOS cells treated with $80 \mu \mathrm{M}$ ATP. (c) BCECF fluorescence in wtCOS, oubRCOS and A7r5 cells under control conditions and during exposure to $1 \mathrm{~mm}$ ouabain. (d) BCECF fluorescence in wtCOS, oubRCOS and A7r5 cells treated with $10 \mathrm{mM} \mathrm{NH}_{4} \mathrm{Cl}$ for $5 \mathrm{~min}$ followed by washout and a further $5 \mathrm{~min}$ monitoring. Results are expressed as the $340: 380 \mathrm{~nm}$ ratio for Ca ${ }^{2+}$ measurements and $480: 440 \mathrm{~nm}$ ratios for $\mathrm{pH}$ measurements. In all, 10 cells were analysed per field of view and results averaged ( $n=3$ cultures for each experimental group).

a
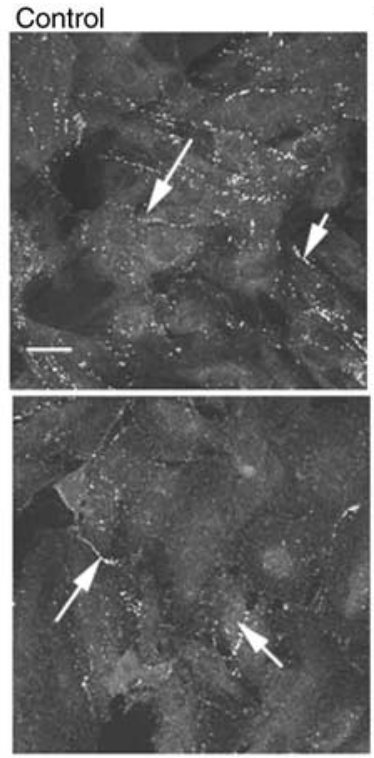

$1 \mathrm{mM}$ oub 1h
$100 \mu \mathrm{M}$ oub $2 \mathrm{~h}$

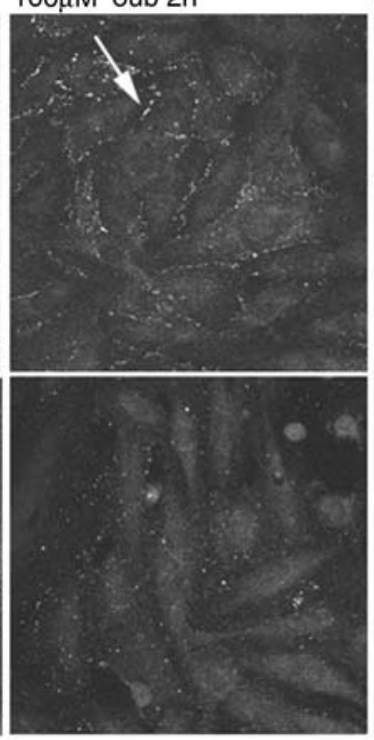

$1 \mathrm{mM}$ oub $2 \mathrm{~h}$
$300 \mu \mathrm{M}$ oub $2 \mathrm{~h}$

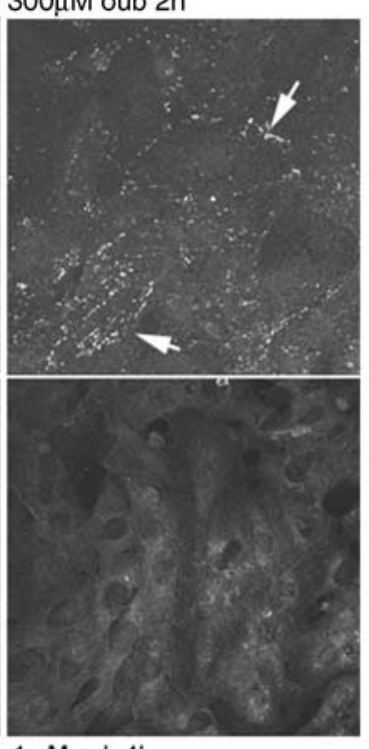

b

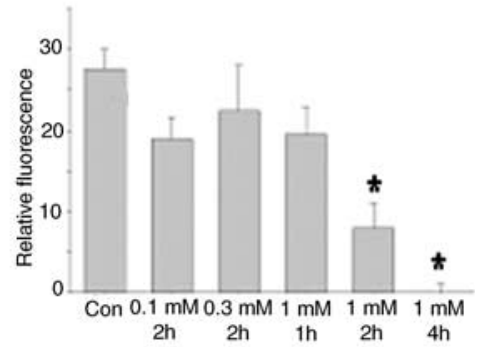

Figure 3 (a) Integrity of gap junction plaques in $\mathrm{A} 7 \mathrm{r} 5$ cells fixed and stained for $\mathrm{Cx} 43$ following incubation with $100 \mu \mathrm{M}-1 \mathrm{mM}$ ouabain for $1-4 \mathrm{~h}$ as indicated. $\mathrm{Bar}=10 \mu \mathrm{m}$; arrows indicate plaques at points of cell-cell contact. (b) Plaque integrity quantified by analysis of $\mathrm{Cx} 43$ fluorescence at the plasma membrane following the various treatments subtracted from background fluorescence. Results are given as mean relative fluorescence \pm s.e.m. Asterisk indicates a significant difference from control $(n=3, P<0.01)$. 
$\mathrm{Cx} 43$
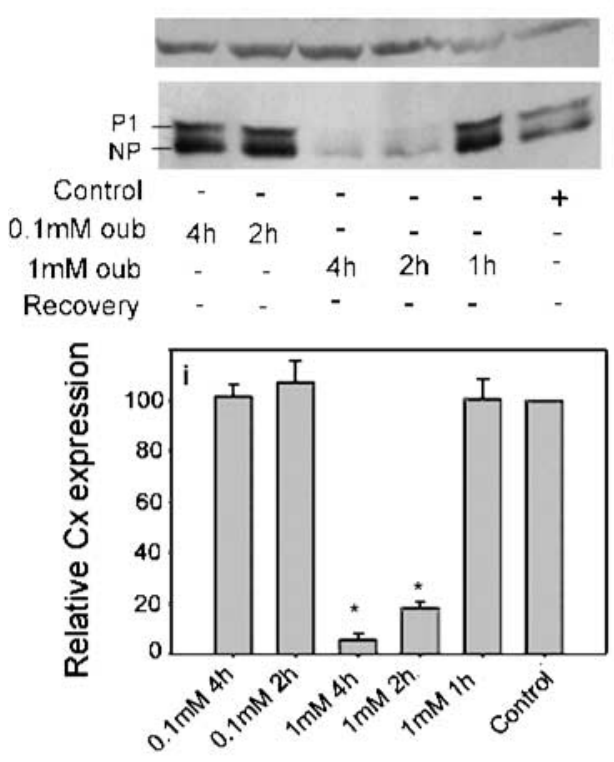

$\mathrm{Cx43}$

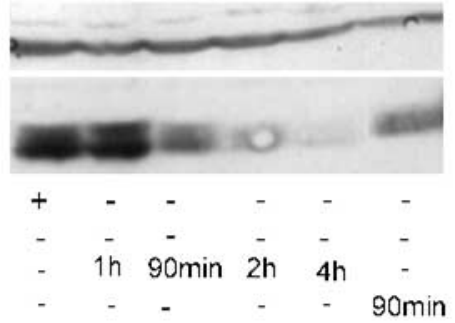

$\mathrm{Cx} 40$

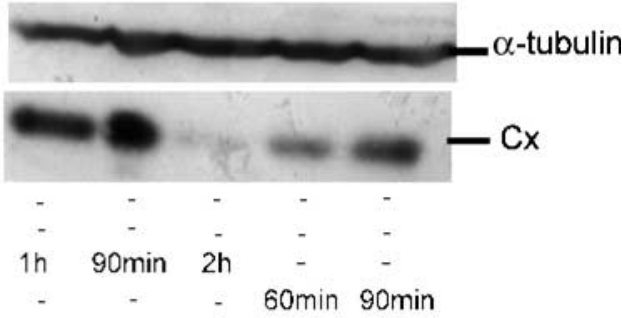

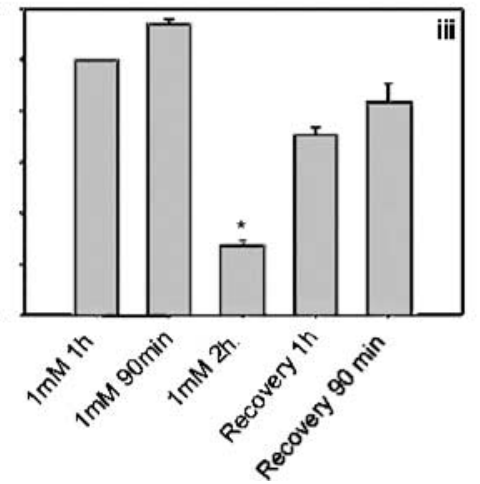

Figure 4 Western blot analysis of $\mathrm{Cx} 43$ and $\mathrm{Cx} 40$ expression profiles in A7r5 cell lysates following treatment with $100 \mu \mathrm{M}$ or $1 \mathrm{~mm}$ ouabain for $1-4 \mathrm{~h}$ and recovery of expression after $2 \mathrm{~h}$ treatment. Equivalent amounts of protein $(50 \mu \mathrm{g})$ were loaded onto the gels and detected using a primary monoclonal antibody to $\alpha$-tubulin as internal standard (top panels) and a polyclonal antibody against $\mathrm{Cx} 43$ or $\mathrm{Cx} 40$ (middle panels) as indicated. (i-iii): Densitometric analysis of the mean Cx expression \pm s.e.m. Asterisk indicates a significant difference from control $(n=3, P<0.05)$. Each blot was standardized as a percentage of the control signal.

phosphorylated states (Figure 4). Treatment with ouabain for up to $4 \mathrm{~h}$ did not alter $\mathrm{Cx} 43$ expression at concentrations of $100 \mu \mathrm{M}$ (Figure 4) or $300 \mu \mathrm{M}$ (not shown). Treatment with $1 \mathrm{~mm}$ ouabain, however, caused a time-dependent decrease in both $\mathrm{Cx} 43$ and $\mathrm{Cx} 40$ expression without affecting the relative $\mathrm{NP} / \mathrm{P} 1$ phosphorylation status of $\mathrm{Cx} 43$. At $1 \mathrm{~h}$ expression levels remained similar to those in nontreated cells, whereas by $2 \mathrm{~h}$ the total amount of $\mathrm{Cx} 43$ or $\mathrm{Cx} 40$ expressed was reduced by $\sim 80 \%$, but was substantially restored $90 \mathrm{~min}$ following drug washout. Expression of Cx43 was further decreased by $4 \mathrm{~h}$ incubation with $1 \mathrm{mM}$ ouabain to levels $<95 \%$ of control (Figure 4).

Cell viability was preserved, even at late time points following treatment with $1 \mathrm{mM}$ ouabain. Under control conditions and following treatment with $1 \mathrm{mM}$ ouabain for periods up to $4 \mathrm{~h}$, the cells were able to process calcein AM and $>95 \%$ of the cells excluded propidium iodide.

\section{Effects of ouabain on Cx43-GFP trafficking in A7r5 cells}

Control experiments were performed in HBS containing $1.3 \mathrm{~mm}$. $\mathrm{Ca}^{2+}$. Cx43-GFP was localised in gap junction plaques and in intracellular particles, which exhibited movement within the cytosol. Superimposed on this vesicular trafficking was movement attributable to the spontaneous contractile activity of this smooth muscle cell line (Figure 5b and supplementary on-line movie). Both types of movement are reflected by the scatter graph showing that many pixel intensities were uniquely red or blue and lie on the $x$ - and $y$ axes, giving a colocalization coefficient $\left(C_{\mathrm{E}}\right)$ of $\sim 0.5$ (Figure 5di). Following $45 \mathrm{~min}$ incubation with $1 \mathrm{mM}$ ouabain, contractile activity and intracellular vesicular $\mathrm{Cx}$ trafficking were both depressed (supplementary movie). This was reflected by greater temporal colocalization of the images (Figures $5 \mathrm{c}$ and dii) and an increase in $C_{\mathrm{E}}$ to $\sim 0.9$ with only limited intracellular trafficking of $\mathrm{Cx}$ protein then being apparent in merged images (Figure 5c). Figures 5e and fillustrate vesicular trafficking of Cx43-GFP protein in A7r5 cells in trace $\mathrm{Ca}^{2+}$ medium, which suppressed spontaneous contractile activity so that the net apparent movement of Cx protein was depressed (Table 1). Under control conditions, the appearance of colour in these merged images nevertheless still revealed substantial trafficking of vesicular connexin protein in the vicinity of the plasma membrane with a $C_{\mathrm{E}}$ of $\sim 0.7$. Addition of $1 \mathrm{mM}$ ouabain resulted in a time-dependent reduction in trafficking that was evident after $30-45 \mathrm{~min}$ and greater after $60-75 \mathrm{~min}$ when $C_{\mathrm{E}}$ approached 1 (Table 1).

\section{Discussion}

We have evaluated the effects of ouabain on gap junctional communication in rat $\mathrm{A} 7 \mathrm{r} 5$ aortic myocytes and model COS-1 and HeLa cell systems. The salient findings are that the glycoside attenuates dye coupling within $\sim 1 \mathrm{~h}$ in each of these cell types and progressively reduces endogenous expression of Cx40 and Cx43 over a period of $4 \mathrm{~h}$ in A7r5 cells.

Intercellular transfer of Lucifer yellow between $\mathrm{A} 7 \mathrm{r} 5$ aortic myocytes, which express the ouabain-resistant rodent $\alpha_{1}$ subunit, was significantly attenuated by ouabain at concentrations $\geqslant 300 \mathrm{M}$, consistent with the known $K_{i}(\sim 100 \mu \mathrm{M})$ of the $\mathrm{Na}^{+} / \mathrm{K}^{+}$-ATPase in this cell line (Vilsen, 1999; Haas et al., 2002). Ouabain concentrations $\geqslant 100 \mu \mathrm{M}$ were required to attenuate dye coupling in oubRCOS cells selected to express 
the rat $\alpha_{1}$ subunit, whereas in wtCOS cells, in which the $\mathrm{K}_{i}$ of the endogenous $\alpha_{1}$ subunit is $\sim 0.3 \mu \mathrm{M}$ (Belusa et al., 2002; Kristensen et al., 2003a), attenuation of dye transfer was evident at $0.1 \mu \mathrm{M}$ and maximal at $10 \mu \mathrm{M}$. Dye transfer was similarly depressed by low micromolar concentrations of ouabain in HeLa cells transfected to express Cx43-GFP. a

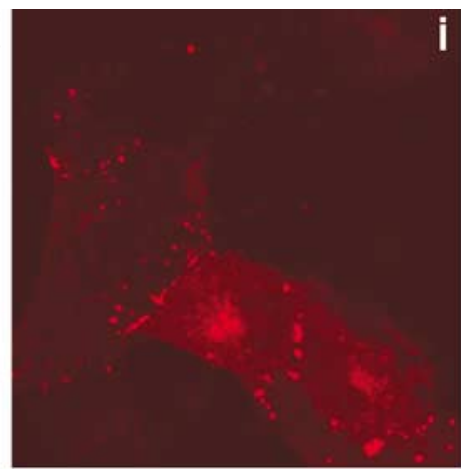

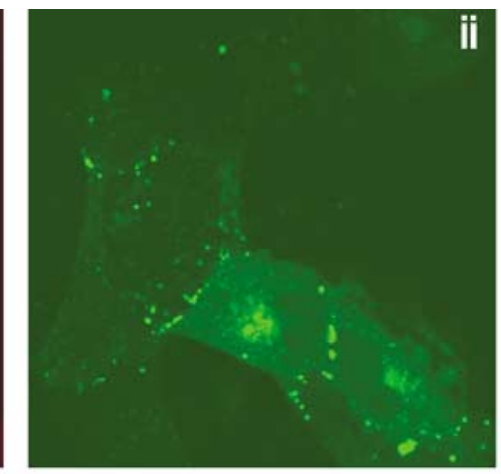

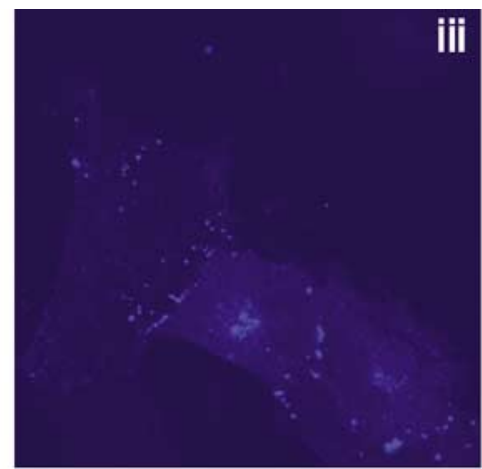

b

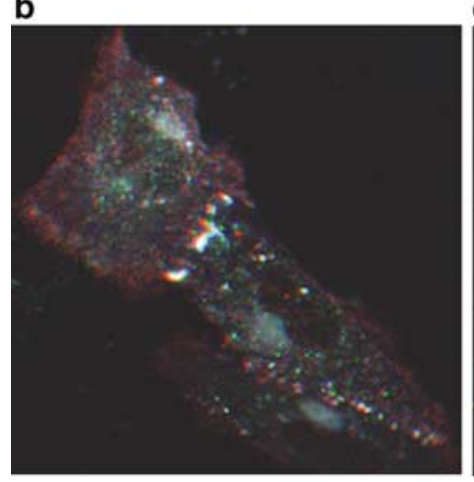

C

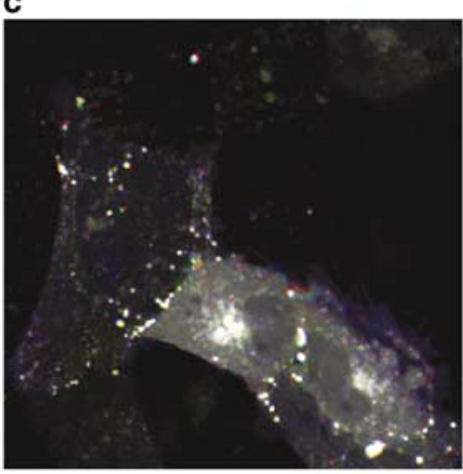

d

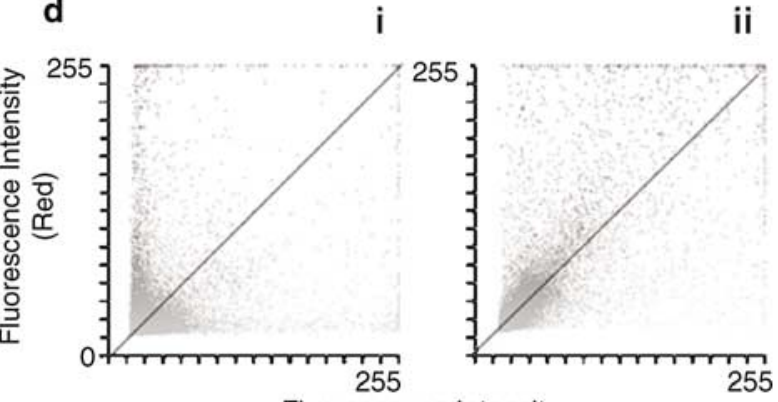

Fluorescence Intensity

(Blue) e
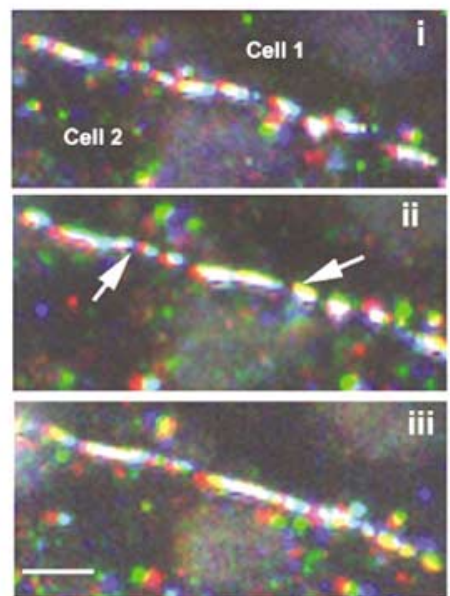

f
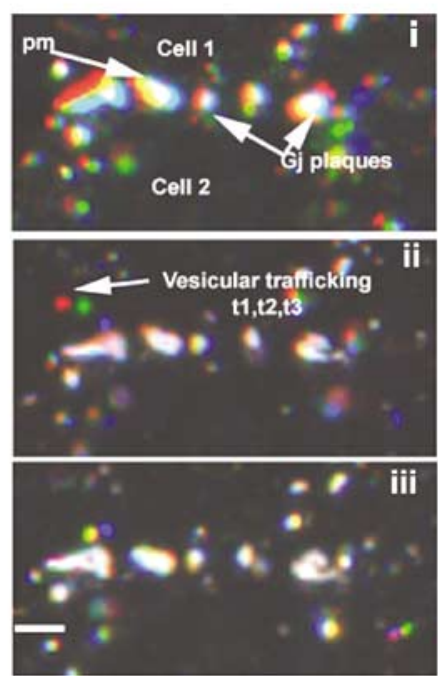

Figure 5 (a) $\mathrm{Cx} 43$-GFP trafficking events in $\mathrm{A} 7 \mathrm{r} 5$ cells in the presence of external $\mathrm{Ca}^{2+}(1.3 \mathrm{mM})$. Images were recorded every $15 \mathrm{~s}$ over a $15 \mathrm{~min}$ time period. To analyse the data, time points $1(15 \mathrm{~s}, t 1), 30(7.5 \mathrm{~min}, t 2)$ and $60(15 \mathrm{~min}, t 3)$ were assigned the colours red (i), green (ii) and blue (iii), respectively. Merging these three images allows the assessment of vesicular trafficking and movement of the cell (b) under control conditions or (c) following treatment for $45 \mathrm{~min}$ with $1 \mathrm{~mm}$ ouabain. (d) Scatter plots of the extent of colocalization of the red and blue channels in the absence (i) and presence (ii) of ouabain, where the line of identity is indicated. (e) Cx43-GFP trafficking events in A7r5 cells in the vicinity of the plasma membrane observed in $\mathrm{Ca}^{2+}$-free medium: (i) merged image for time 1-15 min, (ii) $20-35 \mathrm{~min}$ and (iii) $45-60 \mathrm{~min}$. These findings indicate that imaging of the same cell for prolonged periods did not result in significant photobleaching and that intracellular trafficking was maintained, thus excluding secondary effects from laser damage and focus movement. Bar $=10 \mu \mathrm{m}$. (f) Effects of $1 \mathrm{~mm}$ ouabain on Cx43-GFP trafficking in $\mathrm{Ca}^{2+}$-free medium, with merged images illustrating trafficking (i) before treatment, (ii) $35-45 \mathrm{~min}$ following addition of ouabain and (iii) $60-75 \mathrm{~min}$ following addition of ouabain. $\mathrm{Bar}=5 \mu \mathrm{m}$. 
Table 1 Effects of $1 \mathrm{~mm}$ ouabain on Cx43-GFP movement in A7r5 cells

$\begin{array}{lr}\text { Treatment } & \text { Mean } \pm \text { s.e.m. } \\ \text { Control }+\mathrm{Ca}^{2+}(1.3 \mathrm{mM}) & 0.52 \pm 0.05 \\ \text { Ouabain }+\mathrm{Ca}^{2+}(1.3 \mathrm{mM}) & 0.92 \pm 0.03 \\ \text { Control }\left(\text { trace } \mathrm{Ca}^{2+}\right) & 0.69 \pm 0.07 \\ \text { Ouabain }\left(\text { trace } \mathrm{Ca}^{2+}\right) & 0.94 \pm 0.09\end{array}$

Colocalization coefficients reflecting net movement of the protein were calculated over $15 \mathrm{~min}$ periods $(60-75 \mathrm{~min}$ after treatment with ouabain) from three experimental sets under the various treatments.

Although the rodent $\alpha_{1}$ subunit of A7r5 and oubRCOS cells has the same $\mathrm{K}_{\mathrm{i}}$ for ouabain (Vilsen, 1999), the apparently slightly lower efficacy of the glycoside as an inhibitor of dye transfer in A7r5 cells may simply reflect the ability of this smooth muscle cell line to express high levels of $\mathrm{Cx}$ protein, whereas COS fibroblasts express limited amounts of endogenous Cx43 detectable only by RT-PCR (George et al., 1999; Chaytor et al., 2001). Taken together, these observations indicate that the ability of ouabain to attenuate dye coupling in the four cell lines investigated closely matches the affinity of their respective $\mathrm{Na}^{+} / \mathrm{K}^{+}$-ATPase $\alpha_{1}$ subunits for the glycoside, thus suggesting that specific binding to the enzyme underpins the modulation of downstream events involved in the maintenance of intercellular communication. $\mathrm{Na}^{+} / \mathrm{K}^{+}$ATPases containing $\alpha_{2}$ and $\alpha_{3}$ subunits are unlikely to contribute to the findings as HeLa cells express only the $\alpha_{1}$ subunit, COS-1 cells derive from the kidney which expresses the $\alpha_{1}$ subunit almost exclusively ( $>99 \%$ ), and the dominant $\alpha$ subtype found in A7r5 cells is the ouabain-resistant rodent $\alpha_{1}$ subunit (Tirupattur et al., 1993; Lucking et al., 1996; Zahler et al., 1997). Although small amounts of $\alpha_{2}$ and $\alpha_{3}$ protein may also be detected in cultured rat aortic myocytes (Tirupattur et al., 1993; Songu-Mize et al., 1996), $\mathrm{Na}^{+} / \mathrm{K}^{+}$-ATPases containing these subunits are inhibited by nanomolar concentrations of ouabain (Blanco \& Mercer, 1998), which did not affect transfer of Lucifer yellow between A7r5 cells.

Maximal inhibition of dye coupling was observed at ouabain concentrations known to cause $>95 \%$ inhibition of the ionic activity of the $\mathrm{Na}^{+} / \mathrm{K}^{+}$-ATPase in intact cells, that is, $1 \mathrm{mM}$ for A7r5 cells and $1-10 \mu \mathrm{M}$ for HeLa and wtCOS-1 cells (Zahler et al., 1997; Vilsen, 1999; Belusa et al., 2002; Kristensen et al., 2003a). By increasing intracellular $\left[\mathrm{Na}^{+}\right]_{\mathrm{i}}$, blockade of the pump will alter the transmembrane $\mathrm{Na}^{+}$ gradient for $\mathrm{Na}^{+} / \mathrm{Ca}^{2+}$ and $\mathrm{Na}^{+} / \mathrm{H}^{+}$exchange, and thus in theory modulate cell-cell coupling, because increases in $\left[\mathrm{Ca}^{2+}\right]_{\mathrm{i}}$ or decreases in $\mathrm{pH}_{\mathrm{i}}$ may both reduce the permeability of gap junctions (Schirrmacher et al., 1996; Morley et al., 1996). However, in the A7r5 and COS cells employed in the present study, ouabain failed to evoke changes in intracellular acidification, thus excluding a secondary role for $\mathrm{pH}_{\mathrm{i}}$ in the attenuation of dye transfer in smooth muscle cells. Furthermore, ouabain-induced changes in $\left[\mathrm{Ca}^{2+}\right]_{\mathrm{i}}$ did not correlate with impairment of intercellular coupling. In A7r5 cells, $100 \mu \mathrm{M}$ ouabain caused a transient increase in $\left[\mathrm{Ca}^{2+}\right]_{\mathrm{i}}$, consistent with partial blockade of the $\mathrm{Na}^{+} / \mathrm{K}^{+}$-ATPase, but exerted negligible effects on dye transfer, whereas in oubRCOS cells, $100 \mu \mathrm{M}$ ouabain attenuated dye coupling without affecting $\left[\mathrm{Ca}^{2+}\right]_{\mathrm{i}}$. The observation that $100 \mu \mathrm{M}$ ouabain induced a small rise in $\mathrm{Ca}^{2+}$ levels in wtCOS, but not oubRCOS cells, is consistent with the higher affinity of the wtCOS $\alpha_{1}$ subunit for the glycoside, and is unlikely to reflect nonspecific effects of cell selection because both cell lines were capable of elevating $\left[\mathrm{Ca}^{2+}\right]_{\mathrm{i}}$ in response to ATP. Although ouabain-induced increases in $\left[\mathrm{Ca}^{2+}\right]_{i}$ have been hypothesized to attenuate dye coupling in osteoblasts (Schirrmacher et al., 1996), their apparent dissociation in the present study provides no evidence that these events can be universally regarded as causally related. Indeed, in HeLa cells expressing Cx43-GFP, ouabain attenuated dye transfer at concentrations as low as $1 \mu \mathrm{M}$, but even at $100 \mu \mathrm{M}$ failed to elevate $\left[\mathrm{Ca}^{2+}\right]_{\mathrm{i}}$, presumably because this cell line lacks the $\mathrm{Na}^{+} / \mathrm{Ca}^{2+}$ exchange mechanism and voltage-gated $\mathrm{Ca}^{2+}$ channels (Li et al., 1992; Furman et al., 1995).

We also investigated longer-term effects of ouabain on $\mathrm{Cx}$ expression in A7r5 cells, which express high endogenous levels of $\mathrm{Cx} 40$ and $\mathrm{Cx} 43$ (Chaytor et al., 2001). Immunostaining demonstrated that ouabain caused a progressive concentration- and time-dependent loss of gap junction plaques containing $\mathrm{Cx} 43$, first observed $2 \mathrm{~h}$ after incubation with $1 \mathrm{mM}$ ouabain, with almost total disappearance of membrane staining being apparent by $4 \mathrm{~h}$. In contrast, lower concentrations of ouabain had no effect on $\mathrm{Cx}$ expression, even after prolonged exposure. Western blot analysis of cell extracts confirmed parallel time-dependent loss of $\mathrm{Cx} 40$ and $\mathrm{Cx} 43$ following incubation with $1 \mathrm{mM}$ ouabain, thus indicating that ouabain-induced reductions in $\mathrm{Cx}$ expression were a global phenomenon. $\mathrm{Cx} 43$ can exist as a nonphosphorylated $(42 \mathrm{kDa})$ isoform and two principal phosphorylated isoforms, P1 (44 kDa) and P2 (46 kDa), and in some cell systems connexin phosphorylation modulates cell-cell coupling (Lampe \& Lau, 2000; van Rijen et al., 2000). However, observations that ouabain did not affect the relative expression profile of the NP and $\mathrm{P} 1$ isoforms that predominate in $\mathrm{A} 7 \mathrm{r} 5$ cells provide no evidence that its effects on $\mathrm{Cx} 43$ functionality and expression can be attributed to altered $\mathrm{Cx}$ phosphorylation in vascular smooth muscle. Diminished recruitment of $\mathrm{Cx}$ protein to the cell membrane could, at least in part, contribute to the timedependent loss of membrane plaques as real-time imaging of A 7r5 cells transfected to express $\mathrm{Cx} 43-\mathrm{GFP}$ demonstrated that $1 \mathrm{mM}$ ouabain depressed $\mathrm{Cx}$ trafficking, as evidenced by a decrease in the vesicular movement of Cx43-GFP in the cytosol of cells incubated with the glycoside in the absence of extracellular $\mathrm{Ca}^{2+}$ (a strategy used to suppress the intrinsic rhythmic activity of A7r5 cells). However, the almost total loss of $\mathrm{Cx} 40$ and $\mathrm{Cx} 43$ content observed after incubation with $1 \mathrm{mM}$ ouabain suggests that the glycoside ultimately modulates mechanisms linked to de novo $\mathrm{Cx}$ synthesis in $\mathrm{A} 7 \mathrm{r} 5$ cells. These previously unrecognized effects of ouabain on $\mathrm{Cx}$ trafficking and expression were not secondary to nonspecific cytotoxic actions of the glycoside, as the cells remained able to process calcein AM, and reductions in Cx content were substantially reversed on washout of the glycoside after $\sim 90 \mathrm{~min}$. Although inhibition of the $\mathrm{Na}^{+} / \mathrm{K}^{+}$-ATPase may in theory cause osmotic cell swelling, since three $\mathrm{Na}^{+}$ions are expelled by the pump for every two $\mathrm{K}^{+}$ions that enter, efflux of ions and solutes (e.g. taurine) via other transport systems may compensate or overcompensate. Thus, in mouse neurones a biphasic response is observed with a $10 \%$ increase in cell volume being evident after $1-2 \mathrm{~h}$, but a reduction in cell volume becoming apparent after 3-5h (Xiao et al., 2002), and in the COS-1 cells employed in the present study a 
$40 \%$ decrease in $\mathrm{Na}^{+} / \mathrm{K}^{+}$-ATPase activity causes a $20 \%$ reduction in cell section after $45 \mathrm{~min}$ (Kristensen et al., 2003b). Although we did not formally measure cell volume in the present experiments, no obvious ouabaininduced changes in the contour of $\mathrm{A} 7 \mathrm{r} 5$ cells were evident (see Figure 4), and to our knowledge there are no previous reports causally linking changes in cell volume to alterations in Cx expression.

The effects of ouabain observed in the present study closely mimic the action of glycyrrhetinic acid and its derivatives, which have been widely employed as inhibitors of gap junctional communication and, like ouabain, are steroidal in structure and bind to the $\mathrm{Na}^{+} / \mathrm{K}^{+}$-ATPase, albeit with lower affinity (Terasawa et al., 1992). In epithelial cells, the initial interruption of cell-cell coupling by $18 \alpha$-glycyrrhetinic acid is rapid (within 30-60 min), not associated with changes in the integrity of gap junction plaques or $\mathrm{Cx} 43$ phosphorylation, and is followed by a delayed, concentration-dependent reduction in the expression of Cx43 (Guo et al., 1999). There is good evidence that glycyrrhetinic acid derivatives inhibit endothelium-dependent 'EDHF-type' relaxations by impairing the electrotonic spread of endothelial hyperpolarization into the vascular media via gap junctions (Taylor et al., 1998; Edwards et al., 1999; Yamamoto et al., 1999; Chaytor et al., 2000; Doughty et al., 2000; Kenny et al., 2002), so that the present findings suggest that the ability of ouabain to attenuate such responses might similarly involve diminished gap junction functionality and/or Cx expression. In rat mesenteric, gastric, renal and femoral arteries, for example, the glycoside attenuates or abolishes EDHF-type relaxations only at high concentrations in the range $100 \mathrm{M}-1 \mathrm{mM}$, consistent with the involvement of the ouabain-resistant rodent $\alpha_{1}$ subunit (Doughty et al., 2000; Van de Voorde \& Vanheel, 2000; Jiang \& Dusting, 2001; Savage et al., 2003). By contrast, hyperpolarizations evoked by exogenous $\mathrm{K}^{+}$ions in endothelium-denuded rat arteries can be inhibited by much lower ouabain concentrations $(500 \mathrm{nM})$, and this smooth muscle electrical response to $\mathrm{K}^{+}$is likely to be mediated via $\mathrm{Na}^{+} / \mathrm{K}^{+}$ATPases containing ouabain-sensitive $\alpha_{2}$ and $\alpha_{3}$ subunits, since $\alpha_{1}$ containing isoenzymes may be almost fully activated at normal levels of $\left[\mathrm{K}^{+}\right]_{\mathrm{o}}$ (Blanco \& Mercer, 1998; Weston et al., 2002). Further studies are necessary to determine the mechanisms through which low concentrations of ouabain $(100 \mathrm{nM}-1 \mu \mathrm{M})$ abolish EDHF-type relaxations in other species. For example, porcine and bovine arteries express $\alpha_{1}$, $\alpha_{2}$ and $\alpha_{3}$ subunits that will be sensitive to the glycoside, but impairment of relaxation is time dependent with full inhibition requiring prolonged (>90 min) incubation (Beny \& Schaad, 2000; Büssemaker et al., 2002; Nelli et al., 2003). In this species, it therefore remains conceivable that low concentrations of ouabain modulate gap junction conductance and $\mathrm{Cx}$ expression, as well as $\mathrm{K}^{+}$-induced smooth muscle hyperpolarization.

Further studies are also necessary to determine if the inhibitory effects of ouabain against intercellular coupling and $\mathrm{Cx}$ protein trafficking and expression in $\mathrm{A} 7 \mathrm{r} 5$ cells reflect the loss of normal cellular $\mathrm{Na}^{+} / \mathrm{K}^{+}$homeostasis and inversion of the normal $\left[\mathrm{Na}^{+}\right]_{\mathrm{i}} /\left[\mathrm{K}^{+}\right]_{\mathrm{i}}$ ratio associated with administration of the glycoside, and/or conversion of the $\mathrm{Na}^{+} / \mathrm{K}^{+}$ATPase into a general signal transducer that acts independently of the ionic activity of the enzyme. Ouabain-induced increases in $\left[\mathrm{Na}^{+}\right]_{i}$ have been directly linked to disruption of cytoskeletal components that are known to play a key role in the assembly of gap junctions and are thought to be causally related to decreases in the plasma localization of cell adhesion proteins such as ZO-1 and occludin, which associate with $\mathrm{Cx}$ to form multiprotein complexes involved in cell communication and attachment (Giepmans et al., 2001; Martin et al., 2001; Rajasekaran et al., 2001; Toyofuku et al., 2001). However, ouabain also promotes Src-mediated inter-receptor crosstalk between the $\mathrm{Na}^{+} / \mathrm{K}^{+}$-ATPase and EGFR in A7r5 cells, thereby resulting in the activation of downstream signal transduction pathways (e.g. Ras and p42/44 MAPKs) that effect alterations in cell function and gene expression that are independent of changes in membrane potential and $\left[\mathrm{Na}^{+}\right]_{\mathrm{i}}$ (Haas et al., 2002).

In conclusion, we have shown that ouabain modulates gap junctional communication in A7r5 vascular smooth muscle cells, COS-1 and HeLa cells through an initial action that correlates with its ability to bind to the $\alpha_{1}$ subunits of the $\mathrm{Na}^{+} / \mathrm{K}^{+}$-ATPase isoenzymes expressed in these cells. In confluent A7r5 monolayers, prolonged exposure to ouabain also depresses $\mathrm{Cx}$ trafficking and ultimately abolishes expression of $\mathrm{Cx} 40$ and $\mathrm{Cx} 43$. Although proteome analysis has identified changes in the expression of over 200 vascular smooth muscle proteins following incubation with ouabain (Taurin et al., 2002), its effects on Cx expression have not previously been appreciated. Our observations therefore add Cxs to the increasing number of cellular proteins whose function and expression can be modulated by this glycoside.

\section{Supplementary information}

Supplementary Information accompanies this paper on the British Journal of Pharmacology website (http://www.nature. com/bjp)

A movie of Cx43-GFP trafficking and inherent rhythmic contractile activity in A7r5 cells in HBS containing $1.3 \mathrm{~mm}$ $\mathrm{Ca}^{2+}$ before and after $45 \mathrm{~min}$ incubation with $1 \mathrm{~mm}$ ouabain.

This work was supported by the MRC.

\section{References}

ARISAKA, H., IKEDA, U., TAKAYASU, T., TAKEDA, K., NATSUME, T. \& HOSODA, S. (1988). Ouabain inhibits intracellular $\mathrm{pH}$ recovery from acidosis in cultured mouse heart cells. J. Mol. Cell. Cardiol., 20, $1-3$.

BELUSA, R., AIZMAN, O., ANDERSSON, R.M. \& APERIA, A. (2002). Changes in $\mathrm{Na}^{+} / \mathrm{K}^{+}$-ATPase activity influence cell attachment to fibronectin. Am. J. Physiol., 282, C302-C309.

BENY, J.L. \& SCHAAD, O. (2000). An evaluation of potassium ions as endothelium-derived hyperpolarizing factor in porcine coronary arteries. Br. J. Pharmacol., 131, 965-973.
BERMAN, R.S., MARTIN, P.E.M., EVANS, W.H. \& GRIFFITH, T.M (2002). Relative contributions of NO and gap junctional communication to endothelium-dependent relaxations of rabbit resistance arteries vary with vessel size. Microvasc. Res., 63, 115-128.

BLANCO, G. \& MERCER, R.W. (1998). Isozymes of the Na-K-ATPase: heterogeneity in structure, diversity in function. Am. J. Physiol., 275, F633-F650.

BORIN, M.L., TRIBE, R.M. \& BLAUSTEIN, M.P. (1994). Increased intracellular $\mathrm{Na}^{+}$augments mobilization of $\mathrm{Ca}^{2+}$ from $\mathrm{SR}$ in vascular smooth muscle cells. Am. J. Physiol., 266, C311-C317. 
BÜSSEMAKER, E., WALLNER, C., FISSLTHALER, B \& FLEMING, I. (2002). The Na-K-ATPase is a target for an EDHF displaying characteristics similar to potassium ions in the porcine renal interlobar artery. Br. J. Pharmacol., 137, 647-654.

CHAYTOR, A.T., MARSH, W.L., HUTCHESON, I.R. \& GRIFFITH, T.M. (2000). Comparison of glycyrrhetinic acid isoforms and carbenoxolone as inhibitors of EDHF-type relaxations mediated via gap junctions. Endothelium, 7, 265-278.

CHAYTOR, A.T., MARTIN, P.E.M., EDWARDS, D.H. \& GRIFFITH, T.M. (2001). Gap junctional communication underpins EDHF-type relaxations evoked by $\mathrm{ACh}$ in the rat hepatic artery. Am. J. Physiol., 280, $\mathrm{H} 2441-\mathrm{H} 2450$.

DARROW, B.J., LAING, J.G., LAMPE, P.D., SAFFITZ, J.E. \& BEYER, E.C. (1995). Expression of multiple connexins in cultured neonatal rat ventricular myocytes. Circ. Res., 76, 381-387.

DOUGHTY, J.M., BOYLE, J.P. \& LANGTON, P.D. (2000). Potassium does not mimic EDHF in rat mesenteric arteries. Br. J. Pharmacol., 130, $1174-1182$

EDWARDS, G., DORA, K.A., GARDENER, M.J., GARLAND, C.J. \& WESTON, A.H. (1998). $\mathrm{K}^{+}$is an endothelium-derived hyperpolarizing factor in rat arteries. Nature, 396, 269-272.

EDWARDS, G., FELETOU, M., GARDENER, M.J., THOLLON, C., VANHOUTTE, P.M. \& WESTON, A.H. (1999). Role of gap junctions in the responses to EDHF in rat and guinea-pig small arteries. $B r . J$. Pharmacol., 128, 1788-1794.

FURMAN, I., COOK, O., KASIR, J., LOW, W. \& RAHAMIMOFF, H. (1995). The putative amino-terminal signal peptide of the cloned rat brain $\mathrm{Na}^{+}-\mathrm{Ca}^{2+}$ exchanger gene (RBE-1) is not mandatory for functional expression. J. Biol. Chem., 270, 19120-19127.

GEORGE, C.H., KENDALL, J.M. \& EVANS, W.H. (1999). Intracellular trafficking pathways in the assembly of connexins into gap junctions. J. Biol. Chem., 274, 8678-8685.

GIEPMANS, B.N., VERLANN, I. \& MOOLENAAR, W.H. (2001). Connexin 43 interactions with ZO-1 and $\alpha$ and $\beta$-tubulin. Cell Commun. Adhes., 8, 219-223.

GRIFFITH, T.M., CHAYTOR, A.T., TAYLOR, H.J., GIDDINGS, B.D. \& EDWARDS, D.H. (2002). cAMP facilitates EDHF-type relaxations in conduit arteries by enhancing electrotonic conduction via gap junctions. Proc. Natl. Acad. Sci., 99, 6392-6397.

GUO, Y.H., MARTINEZ-WILLIAMS, C., GILBERT, K.A. \& RANNELS, D.E. (1999). Inhibition of gap junction communication in alveolar epithelial cells by $18 \alpha$-glycyrrhetinic acid. Am. J. Physiol., 20, L1018 - L1026.

HAAS, M., WANG, H., TIAN, J. \& XIE, Z. (2002). Src-mediated interreceptor cross-talk between the $\mathrm{Na}^{+} / \mathrm{K}^{+}$-ATPase and the epidermal growth factor receptor relays the signal from ouabain to mitogenactivated protein kinases. J. Biol. Chem., 77, 18694-18702.

HARRIS, D., MARTIN, P.E., EVANS, W.H., KENDALL, D.A., GRIFFITH, T.M. \& RANDALL, M.D. (2000). Role of gap junctions in endothelium-derived hyperpolarizing factor responses and mechanisms of $\mathrm{K}^{+}$-relaxation. Eur. J. Pharmacol., 402, $119-128$.

HILL, C.E., RUMMERY, N., HICKEY, H. \& SANDOW, S.L. (2002). Heterogeneity in the distribution of vascular gap junctions and connexins: implications for function. Clin. Exp. Pharmacol. Physiol., 29, 20-25.

JIANG， F. \& DUSTING， G.J. (2001). Endothelium-dependent vasorelaxation independent of nitric oxide and $\mathrm{K}^{+}$release in isolated renal arteries of rats. Br. J. Pharmacol., 132, 1558-1564.

JUHASZOVA, M. \& BLAUSTEIN, M.P. (1997). $\mathrm{Na}^{+}$pump low and high ouabain affinity $\alpha$ subunit isoforms are differently distributed in cells. Proc. Natl. Acad. Sci., 94, 1800-1805.

KENNY, L.C., BAKER, P.N., KENDALL, D.A., RANDALL, M.D. \& DUNN, W.R. (2002). The role of gap junctions in mediating endothelium-dependent responses to bradykinin in myometrial small arteries isolated from pregnant women. Br. J. Pharmacol., 136, $1085-1088$.

KO, Y.S., COPPEN, S.R., DUPONT, E., ROTHERY, S. \& SEVERS, N.J. (2001). Regional differentiation of desmin, connexin43, and connexin45 expression patterns in rat aortic smooth muscle. Arterioscler. Thromb. Vasc. Biol., 21, 355-364.

KRISTENSEN, B., BIRKELUND, S. \& JORGENSEN, P.L. (2003a). Trafficking of Na,K-ATPase fused to enhanced green fluorescent protein is mediated by protein kinase A or C. J. Memb. Biol., 191, $25-36$.
KRISTENSEN, B., BIRKELUND, S. \& JORGENSEN, P.L. (2003b). Expression of a Na,K-ATPase chimera in COS cells. Ann. NY Acad. Sci., 986, 546-547.

KRUGER, O., BENY, J.L., CHABAUd, F., TRAUB, O., THEIS, M. BRIX, K., KIRCHHOFF, S. \& WILLECKE, K. (2002). Altered dye diffusion and upregulation of connexin 37 in mouse aortic endothelium deficient in connexin40. J. Vasc. Res., 39, $160-172$.

LAMPE, P.D. \& LAU, A.F. (2000). Regulation of gap junctions by phosphorylation of connexins. Arch. Biochem. Biophys., 384, $205-215$.

LI, P., SEMPOWSKI, T.C., GERSHENGORN, G.D. \& HINKLE, P.M (1992). Characterization of the calcium response to thyrotropinreleasing hormone (TRH) in cells transfected with TRH receptor complementary DNA: importance of voltage-sensitive calcium channels. Mol. Endocrinol., 6, 1393-1402.

LUCKING, K., NIELSEN, J.M., PEDERSEN, P.A. \& JORGENSEN, P.L. (1996). Na-K-ATPase isoform $(\alpha 3, \alpha 2, \alpha 1)$ abundance in rat kidney estimated by competitive RT-PCR and ouabain binding. Am. J. Physiol., 271, F253-F260.

MANDERS, E.M., VERBEEK, F.J. \& ATEN, J.A. (1993). Measurement of colocalisation of objects in dual colour confocal microscopy. J. Microscopy, 169, 375-382.

MARTIN, P.E.M., BLUNDELl, G., AHMAD, S., ERRINGTON, R.J. \& EVANS, W.H. (2001). Multiple pathways in the trafficking and assembly of Connexin 26, 32 and 43 into Gap junctional intercellular communication channels. J. Cell Sci., 114, $3845-3855$.

MORLEY, G.E., TAFFET, S.M. \& DELMAR, M. (1996). Intramolecular interactions mediate $\mathrm{pH}$ regulation of connexin43 channels. Biophys. J., 70, 1294-1302.

NELLI, S., WILSON, W.S., LAIDLAW, H., LLANO, A., MIDDLETON, S., PRICE, A.G. \& MARTIN, W. (2003). Evaluation of potassium ion as the endothelium-derived hyperpolarizing factor (EDHF) in the bovine coronary artery. Br. J. Pharmacol., 139, 982-988.

RAJASEKARAN, S.A., PALMER, L.G., MOON, S.Y., PERALTA SOLER, A., APODACA, G.L., HARPER, J.F., ZHENG, Y. \& RAJASKARAN, A.K. (2001). $\mathrm{Na}^{+} / \mathrm{K}^{+}$-ATPase activity is required for formation of tight junctions, desmosomes and induction of polarity in epithelial cells. Mol. Biol. Cell., 12, 3717-3732.

ROOS, A. \& BORON, W.F. (1981). Intracellular pH. Physiol. Rev., 61, $296-434$.

SAFFITZ, J.E., LAING, J.G. \& YAMADA, K.A. (2000). Connexin expression and turnover: implications for cardiac excitability. Circ. Res., 86, 723-728.

SANDOW, S.L., TARE, M., COLEMAN, H.A., HILL, C.E. \& PARKINGTON, H.C. (2002). Involvement of myoendothelial gap junctions in the actions of endothelium-derived hyperpolarizing factor. Circ. Res., 90, 1108-1113.

SATO, K. \& AOKI, K. (1991). Early and late contraction induced by ouabain in human umbilical arteries. Br. J. Pharmacol., 103, $1525-1529$.

SAVAGE, D., PERKINS, J., HONG LIM, C. \& BUND, S.J. (2003) Functional evidence that $\mathrm{K}^{+}$is the non-nitric oxide, nonprostanoid endothelium-derived relaxing factor in rat femoral arteries. Vasc. Pharmacol., 40, 23-28.

SCHIRRMACHER, K., NONHOFF, D., WIEMANN, M., PETERSONGRINE, E., BRINK, P.R. \& BINGMANN, D. (1996). Effects of calcium on gap junctions between osteoblast-like cells in culture. Calcif. Tissue Int., 59, 259-264.

SONGU-MIZE, E., LIU, X., STONES, J.E. \& HYMEL, L.J. (1996). Regulation of $\mathrm{Na}^{+}, \mathrm{K}^{+}$-ATPase -subunit expression by mechanical strain in aortic smooth muscle cells. Hypertension, 27 , $827-832$.

SOUZA, M.M., GROSS, S., BOYLE, R.T. \& LIEBERMAN, M. (2000). $\mathrm{Na}^{+} / \mathrm{K}^{+}$-ATPase inhibition during cardiac myocyte swelling: involvement of intracellular $\mathrm{pH}$ and $\mathrm{Ca}^{2+}$. Mol. Cell. Biochem. 210, $173-183$

TAURIN, S., SEYRANTEPE, V., ORLOV, S.N., TREMBLAY, T.L., THIBAULT, P., BENNETT, M.R., HAMET, P. \& PSHEZHETSKY, A.V. (2002). Proteome analysis and functional expression identify mortalin as an antiapoptotic gene induced by elevation of $\left[\mathrm{Na}^{+}\right]_{\mathrm{i}} /$ $\left[\mathrm{K}^{+}\right]_{\mathrm{i}}$ ratio in cultured vascular smooth muscle cells. Circ. Res., 91, 915-922. 
TAYLOR, H.J., CHAYTOR, A.T., EVANS, W.H. \& GRIFFITH, T.M. (1998). Inhibition of the gap junctional component of endotheliumdependent relaxations in rabbit iliac artery by $18 \alpha$-glycyrrhetinic acid. Br. J. Pharmacol., 125, 1-3.

TERASAWA, T., OKADA, T., HARA, T. \& ITOH, K. (1992). Glycyrrhetinic acid derivatives as potent inhibitors of $\mathrm{Na}^{+} / \mathrm{K}^{+}$-ATPase. Synthesis and structure-activity relationships. Eur. J. Med. Chem., 27, 345-351.

TOYOFUKU, T., AKAMATSU, Y., ZHANG, H., KUZUYA, T., TADA, M. \& HORI, M. (2001). c-Src regulates the interaction between connexin-43 and ZO-1 in cardiac myocytes. J. Biol. Chem., 276, $1780-1788$.

TIRUPATTUR, P.R., RAM, J.L., STANDLEY, P.R. \& SOWERS, J.R. (1993). Regulation of $\mathrm{Na}^{+}, \mathrm{K}^{+}$-ATPase gene expression by insulin in vascular smooth muscle cells. Am. J. Hypertens., 6, 626-629.

UJIIE, H., CHAYTOR, A.T., BAKKER, L.M. \& GRIFFITH, T.M. (2003) Essential role of gap junctions in NO- and prostanoid-independent relaxations evoked by acetylcholine in rabbit intracerebral arteries. Stroke, 34, 544-550.

VAN DE VOORDE, J. \& VANHEEL, B. (2000). EDHF-mediated relaxation in rat gastric small arteries: influence of ouabain $/ \mathrm{Ba}^{2+}$ and relation to potassium ions. J. Cardiovasc. Pharmacol., 35, $543-548$.

VAN RIJEN, H.V., VAN VEEN, T.A., HERMANS, M.M. \& JONGSMA, H.J. (2000). Human connexin40 gap junction channels are modulated by cAMP. Cardiovasc. Res., 45, 941-951.
VILSEN, B. (1999). Mutant Phe788 $->$ Leu of the $\mathrm{Na}^{+} / \mathrm{K}^{+}$-ATPase is inhibited by micromolar concentrations of potassium and exhibits high $\mathrm{Na}^{+}$-ATPase activity at low sodium concentrations. Biochem., 38, $1389-1400$.

WESTON, A.H., RICHARDS, G.R., BURNHAM, M.P., FELETOU, M. VANHOUTTE, P.M. \& EDWARDS, G. (2002). $\mathrm{K}^{+}$-induced hyperpolarization in rat mesenteric artery: identification, localization and role of $\mathrm{Na}^{+} / \mathrm{K}^{+}$-ATPases. Br. J. Pharmacol., 136, $918-926$.

XIAO, A.Y., WEI, L., XIA, S., ROTHMAN, S. \& YU, S.P. (2002) Ionic mechanism of ouabain-induced concurrent apoptosis and necrosis in individual cultured cortical neurones. J. Neurosci., 22, $1350-1362$.

YAMAMOTO, Y., IMAEDA, K. \& SUZUKI, H. (1999). Endothelium-dependent hyperpolarization and intercellular electrical coupling in guinea-pig mesenteric arterioles. J. Physiol., 514, $505-513$.

ZAHLER, R., ZHANG, Z.T., MANOR, M. \& BORON, W.F. (1997). Sodium kinetics of $\mathrm{Na}, \mathrm{K}-\mathrm{ATPase}$ alpha isoforms in intact transfected HeLa cells. J. Gen. Physiol., 110, 201-213.

(Received July 22, 2003

Revised September 8, 2003 Accepted September 20, 2003) 